\title{
Total lightning activity in thunderstorms over Paris
}

\author{
M.P. Boussaton, S. Soula, S. Coquillat* \\ Laboratoire d'Aérologie, UMR UPS/CNRS N5560, Observatoire Midi-Pyrénées, Toulouse, France
}

\begin{abstract}
A statistical study of two groups of storms that occurred in the Paris area (France) during summer 2000 has been realized. The first group includes 26 high radar reflectivity (HRR) storms with radar reflectivity values exceeding $60 \mathrm{dBZ}$ while the second one includes 19 moderate radar reflectivity (MRR) storms with a maximum radar reflectivity value between 50 and $55 \mathrm{dBZ}$. The radar reflectivity was provided by a C-band radar and the total lightning activity (cloud-to-ground (CG) and intra-cloud (IC) flashes) was provided by the French Météorage network and a Safir device. HRR storms seem to be characterized by a longer lifetime, and a more extended convective area. On average, they produce more CG and IC flashes than MRR storms. However, a large variability in the number, the rate, and the type of flashes is observed. The HRR storms producing the highest IC flash rates (above $100 \mathrm{~min}^{-1}$ ) exhibit the lowest CG flash proportion (1.2 and 4.3\%). Most of the HRR storms exhibit a peak lightning activity when the radar reflectivity is strong at low level within the cloud. However, several cases of these storms show a large time lag between the strong lightning production and the presence of high radar reflectivity values at low level. Some possible explanations of these observations, taking into account cloud dynamics, microphysics and lightning initiation, are discussed.
\end{abstract}

\section{Introduction}

The relationship between severe weather (characterized by large hailstones at the ground with a diameter higher than $19 \mathrm{~mm}$, a sustained surface wind in excess of $26 \mathrm{~m} \mathrm{~s}^{-1}$, or the occurrence of a tornado, according to MacGorman and Rust (1998)) and lightning activity is not clearly understood. In his review about the electrification of severe storms, Williams (2001) noted a large variability in the relationships between lightning and manifestations like tornadoes and large hail (diameter higher than $19 \mathrm{~mm}$ ). Concerning cloud-to-ground (CG)

\footnotetext{
* Corresponding author.

E-mail address: sylvain.coquillat@aero.obs-mip.fr (S. Coquillat).
}

lightning, Changnon (1992) observed that the CG lightning centers typically developed 9 min before hail at a point $5 \mathrm{~km}$ upstorm from first hailfall, which suggests that CG flashes begin as the hailstones are developing aloft. On the contrary, an anticorrelation between hail production and negative CG $(-\mathrm{CG})$ flashes was observed in several studies (Carey and Rutledge, 1998; Lang et al., 2000; Knupp et al., 2003). Soula et al. (2004) pointed out a drastic decrease of the $-\mathrm{CG}$ rate associated with the presence of hail. Several observations display dominant positive $\mathrm{CG}(+\mathrm{CG})$ lightning flashes during the mature phase of various kinds of violent storms (tornadoes, supercells, hailstorms) and for long periods (several tens of minutes) (Reap and MacGorman, 1989; Branick and Doswell, 1992; Stolzenburg, 1994; MacGorman and Burgess, 1994; Carey and Rutledge, 1998). This $+\mathrm{CG}$ activity is remarkable because its density is 
comparable to the negative CG density generally observed below the non severe storms. However, severe weather can occur in the absence of high + CG flash activity (Williams, 2001; Carey et al., 2003). During the lifetime of the storm, the dominant polarity of the CG flashes can change with both chronologies possible. So, by analyzing a tornadic F5 supercell, Seimon (1993) observed a reversal in dominant $\mathrm{CG}$ polarity from positive to negative when tornado touched down. On the contrary, by analyzing a case of hailstorm from the MAP (Mesoscale Alpine Program) experiment, Soula et al. (2004) observed a reversal from negative to positive when hail was produced.

Few studies have considered the total lightning activity (intracloud (IC) and CG flashes) and in the case studies of severe storms, a very high IC-to-CG ratio was observed during the severe stage (Carey and Rutledge, 1998). On the other hand, a high flash rate does not involve systematically severe weather (Williams, 2001). Williams et al. (1999), by studying 32 severe storms in Florida, showed that an abrupt increase in the total flash rate systematically precedes the severe weather at the ground by 5 to $20 \mathrm{~min}$. More recently Lang et al. (2005), MacGorman et al. (2005), and Wiens et al. (2005) focused on the inverted polarity electrical structures of severe thunderstorms during the Severe Thunderstorm Electrification and Precipitation Study (STEPS) that took place on the Colorado-Kansas border in summer 2000. Lang et al. (2005) showed that the increase in $+\mathrm{CG}$ production in a supercell was coincident with the presence of hail aloft. They noted that most of the $+\mathrm{CG}$ tended to initiate in or near regions of hail and high density graupel aloft. MacGorman et al. (2005) reported a high IC flash rate in a supercell producing large hail (29 June 2000). Balloon soundings and a lightning mapping array allowed them to detect inverted polarities for cloud flashes and cloud charge structures that probably issued from the positive charging of graupel in the updraft. This positive charging would result from a high rime accretion rate on graupel favored by the presence of high liquid water content at high level due to the elevation of the weak echo vault. MacGorman et al. pointed out that the inverted polarity and $+\mathrm{CG}$ production of this kind of supercell is favored by a strong or increasingly strong updraft, a drier climate, and microphysical processes related to severe hail.

The purpose of this paper is to present a comparison of the main characteristics in term of lightning activity for two groups of storms observed in the Paris area during summer 2000. One group consists of 26 high radar reflectivity (HRR) thunderstorms (maximum radar reflectivity factor higher than $60 \mathrm{dBZ}$ ) and the other consists of 19 moderate radar reflectivity (MRR) thunderstorms (maximum radar reflectivity factor between 50 and $55 \mathrm{dBZ}$ ). A systematic study of the total lightning activity of all HRR storms is presented in order to better analyze the behavior of this type of storm.

\section{Data description and analysis method}

Total lightning activity was observed with the Météorage network and a Safir system. The Météorage network covers the whole of France. It is composed of Lightning Location and Protection (LLP) sensors and uses two techniques of location of the strokes, the Direction Finder (DF) combined with the Time-Of-Arrival (TOA) (Cummins et al., 1998). It provides for each CG flash the location of the ground impact, the occurrence time, the number of strokes (multiplicity), and the peak current of each stroke, with an efficiency larger than $90 \%$ for the study area. As indicated by several authors, some positive CG flashes detected by the DF sensors can be misidentified cloud flashes (Wacker and Orville, 1999a,b; Orville and Huffines, 2001; Carey et al., 2003). So, the positive flashes recorded by the network were eliminated if their peak current was lower than $10 \mathrm{kA}$. The Safir system, which is no longer in operation, covered an area of about $120 \mathrm{~km}$ in radius around Paris. It allowed characterization of the total lightning activity. It was composed of three stations, each one detecting by interferometric technique the direction of the Very High Frequency (VHF) sources produced by different phases of any lightning discharge. The combination of the three different directions provided the 2D location of the VHF sources with a $100-\mu$ s time resolution. Several temporal and spatial criteria permitted identification of isolated sources, the beginning and end of lightning flashes, and intermediate sources (Richard and Lojou, 1996). An underestimation of IC flashes is likely at the beginning and/or at the end of the observation period (i.e. at the edges of the domain) for the cells that crossed the Safir detection area. This remains, though marginal, and should not affect substantially the results presented. In the following, the calculation of the flash rates does not take into account the isolated sources. The IC flashes are distinguished by removing the $\mathrm{CG}$ flashes from the total flashes provided by the Safir system.

Precipitation data were provided by the 5-cm Trappes radar $\left(48^{\circ} 46^{\prime} \mathrm{N} ; 2^{\circ} 01^{\prime} \mathrm{E}\right.$, close to Paris) that has a range of detection of $250 \mathrm{~km}$ and produces one image every $5 \mathrm{~min}$. Its resolution is $1 \times 1 \mathrm{~km}^{2}$. The images are builtup with two beam elevations: $1.5^{\circ}$ and $0.4^{\circ}$ for $0-50 \mathrm{~km}$ and $50-250 \mathrm{~km}$ distances from the radar, respectively. 
The aperture angle is $1.3^{\circ}$. Since we only consider thundercells located in the Safir observation area (i.e. $120 \mathrm{~km}$ around Trappes), the radar echoes analyzed were detected at altitudes lower than $3.2 \mathrm{~km}$.

The CG and IC flashes are associated with each individual cell as follows: for each radar image (every $5 \mathrm{~min}$ ), the cell area is defined by a radar reflectivity factor higher than $0 \mathrm{dBZ}$ around its core, and all flashes detected in this area during the $5 \mathrm{~min}$ around the time of the scan are selected. Thus, flash rates can be calculated for every 5-min period.

A reflectivity threshold of $60 \mathrm{dBZ}$ is chosen as a criterion for HRR thunderstorms. This high value corresponds to a probable production of heavy rain and/or hail. If we consider the usual $Z-R$ relationships corresponding to convective rains (the mean $\mathrm{Z}-\mathrm{R}$ relationship for thunderstorms derived from Battan (1973); WSR88D convective in Fulton et al. (1998); Austin (1987); see Salek et al. (2004) for a review), $60 \mathrm{dBZ}$ would correspond to a rain rate higher than $200 \mathrm{~mm} \mathrm{~h}^{-1}$ over a surface of $1 \times 1 \mathrm{~km}^{2}$ according to the radar resolution. Since such a high rain rate is unlikely to be produced in the Paris area (see Fulton et al., 1998), it is therefore expected that cells presenting reflectivity factors over $60 \mathrm{dBZ}$ produce hail. Moreover, this threshold of $60 \mathrm{dBZ}$ is in agreement with the criterion of Mason (1971), and with the method of Auer (1994) whatever the cloud top temperature is for the hail detection.

Thus, we studied all the electrically active storms for which the radar reflectivity factor exceeded $60 \mathrm{dBZ}$ for at least one radar scan. Another group corresponding to storms for which the maximal radar reflectivity factor $\left(Z_{\max }\right)$ was between 50 and $55 \mathrm{dBZ}$ (MRR storms) will provide comparative data. In the following, the term $A$ $(\tau)$, where $\tau$ is the reflectivity factor value in $\mathrm{dBZ}$, designates the area in which the reflectivity factor $\mathrm{Z}$ is higher than $\tau$.

\section{Results}

\subsection{Overview}

During summer 2000, 26 HRR thunderstorms were observed in the Safir area during the storm lifetime. On the other hand, 19 storms located in the Safir area presented maximal radar reflectivity factors between 50 and $55 \mathrm{dBZ}$. Table 1 displays the range of values and the average characteristics of the HRR and MRR thunderstorms.

The peak total flash rate measured is around $17 \mathrm{~min}^{-1}$ on average for the 2 groups of cells, which is of the same order of magnitude as the value of $10 \mathrm{~min}^{-1}$ suggested by Lang and Rutledge (2002) for typical convection.
For each cell, the mean flash rates are calculated for the whole cell lifetime whereas the maximal flash rates are the highest values reached during this period. An average is then realised for the different rates over the totality of the cells ( 26 cells for the first group, 19 for the second). For each considered parameter, the minimal and maximal values found in each group are indicated in

Table 1

Characteristics of the two groups of cells : mean values, and minimal and maximal values in parentheses for each parameter

\begin{tabular}{|c|c|c|c|}
\hline & $\begin{array}{l}\text { Group of HRR } \\
\text { cells ( } 26 \text { cells) }\end{array}$ & $\begin{array}{l}\text { Group of MRR } \\
\text { cells ( } 19 \text { cells) }\end{array}$ & $\begin{array}{l}\text { Probability that } \\
\text { the } 2 \text { groups } \\
\text { averages are } \\
\text { identical }\end{array}$ \\
\hline $\begin{array}{l}\text { Duration } \\
\text { (hh:mm) }\end{array}$ & $1: 48(0: 45-3: 45)$ & $1: 22(0: 50-2: 00)$ & 0.02 \\
\hline $\begin{array}{l}\text { Mean area } \\
\qquad \mathrm{A}(0)\left(\mathrm{km}^{2}\right)\end{array}$ & 394 (194-998) & $391(156-775)$ & 0.96 \\
\hline $\begin{array}{l}\text { Mean area } \\
\qquad \mathrm{A}(40)\left(\mathrm{km}^{2}\right)\end{array}$ & $106(40-333)$ & $79(25-146)$ & 0.09 \\
\hline $\begin{array}{l}\text { Number of } \\
\quad+\text { CG flashes } \\
\text { per cell }\end{array}$ & $2.6(0-18)$ & $3.4(0-26)$ & 0.62 \\
\hline $\begin{array}{l}\text { Number of } \\
\text {-CG flashes } \\
\text { per cell }\end{array}$ & $72.8(0-487)$ & $19.2(0-95)$ & 0.01 \\
\hline $\begin{array}{l}\text { Percentage } \\
\text { of }+\mathrm{CG} \\
\text { flashes }(\%)\end{array}$ & $8.6(0-100)$ & $21.7(0-100)$ & 0.10 \\
\hline $\begin{array}{l}\text { Number of IC } \\
\text { flashes per } \\
\text { cell }\end{array}$ & $1079(72-11,209)$ & $414(0-2092)$ & 0.17 \\
\hline $\begin{array}{l}\text { Percentage of } \\
\text { CG flashes } \\
(\%)\end{array}$ & $12.2(1.2-31)$ & $9.5(1-36.4)$ & 0.32 \\
\hline $\begin{array}{l}\text { Mean CG } \\
\text { flash rate } \\
\quad\left((5 \mathrm{~min})^{-1}\right)\end{array}$ & $3.1(0.2-14.9)$ & $1.4(0.1-6.1)$ & 0.02 \\
\hline $\begin{array}{l}\text { Maximal CG } \\
\text { flash rate } \\
\left((5 \mathrm{~min})^{-1}\right)\end{array}$ & $9.6(1-33)$ & $4.3(2-12)$ & 0.00 \\
\hline $\begin{array}{l}\text { Mean IC flash } \\
\text { rate } \\
\quad\left((5 \mathrm{~min})^{-1}\right)\end{array}$ & $38.5(4.4-429.7)$ & $23.4(0.7-116.2)$ & 0.30 \\
\hline $\begin{array}{l}\text { Maximal IC } \\
\text { flash rate } \\
\left((5 \mathrm{~min})^{-1}\right)\end{array}$ & $84.5(14-514)$ & $51.2(4-224)$ & 0.20 \\
\hline
\end{tabular}

The mean flash rates are calculated for the whole cell lifetime whereas the maximal flash rates are the highest values reached during this time. An average is realised for the different rates over the totality of the cells ( 26 cells for the first group, 19 for the second one). The percentage of CG lightning is defined as the ratio between CG flashes and total flashes ( $\mathrm{CG}$ and IC flashes). The percentage of + CG lightning is defined as the ratio between $+\mathrm{CG}$ flashes and total CG flashes (+CG and $-\mathrm{CG}$ flashes). The last column gives the result of the Student test for small samples, which corresponds to a probability of identical average for the two groups. 
parentheses. In order to evaluate the possible differences between the 2 groups, a statistical test to compare small samples is realised for each parameter. The Student test for small samples is used and the $p$-value of this test, which corresponds to a probability of identical average for the two groups, is displayed in the last column of Table 1. The percentage of CG lightning flashes is defined as the ratio between CG flash number and total flash number ( $\mathrm{CG}$ and IC flashes). The percentage of $+\mathrm{CG}$ lightning flashes is defined as the ratio between $+\mathrm{CG}$ flash number and total $\mathrm{CG}$ flash number ( + CG and $-\mathrm{CG}$ flashes).

Whatever the group, the dimensions of the cells, represented by the area $A(0)$, are mainly the same but the convective area, defined by the surface $A(40)$ (Stolzenburg et al., 1998), seems more extended in the case of HRR cells. Moreover, the duration of these HRR cells is longer. Actually, the meteorological soundings available in the vicinity of 9 of the HRR cases show strong altitude winds and strong vertical wind shear, which generally prevents rapid cell collapse. The lightning production (number of flashes per cell, mean and maximal CG and IC flash rates) is largely higher for HRR cells than for MRR ones. However, for the maximal CG flash rate, the range is larger in the HRR group (1-33) than in the MRR group (2-12). The minimum values of these ranges indicate that an HRR storm can produce very low CG flash rate during its whole lifetime, even lower than MRR storms. On the other hand, the production of $+\mathrm{CG}$ is lower for the HRR group, which differs from what is usually observed. Yet, the statistical test applied to this parameter shows that the difference has little significance. The percentage of CG lightning is slightly higher in HRR cells.

One interesting feature inferred from Table 1 is the wide range of the lightning activity characteristics in each group of cells. For each parameter considered in Table 1, the ranges in both groups largely overlap. As an example, the maximum IC flash rate ranges from 14 to 514 and from 4 to 224 per $5 \mathrm{~min}$ for HRR and MRR, respectively. In the same way, the $+\mathrm{CG}$ percentage ranges from $0 \%$ to $100 \%$ for both groups, meanwhile the CG percentage ranges between about $1 \%$ to $35 \%$ for both groups too.

\subsection{Time series of individual HRR cells}

The time series of radar reflectivity and lightning production are considered for the first group of cells, and presented in Fig. 1. Four parameters are considered in the graphs: the $\mathrm{CG}$ flash rate, the IC flash rate, $A(60)$, and $A(55)$. Several behaviours are observed.
For most of the HRR cells, the time series of total flash rate and high radar reflectivity areas are in good agreement. Especially, one can notice a very good temporal correlation between the IC and CG flash rates and $A(55)$. One can give as examples, cell 1 on 5 May, cell 3 on 11 May, the cell on 13 May, or cell 1 on 16 May. This expected behaviour further confirms that lightning activity is typically associated with the mature stage of the storm, especially with the presence of strong precipitation at low level (MacGorman and Rust, 1998). For some others cells (6 May; 9 May; 2 July; 2 August; 19 August), the high reflectivity factors at a low level appear some tens of minutes after a peak in lightning activity. This behaviour matches with the typical scheme of Williams et al. (1999) with lower flash rates. Finally, several cells (11 May, cell 1; 11 May, cell 2; 7 July, cell 1; 7 July, cell 4; 18 August) exhibit unexpected features: they begin with a period of high reflectivity values while few flashes are detected, followed by a period during which the reflectivity factor is lower and the lightning rate reaches a maximum. This quite atypical behaviour seems to indicate a possible inhibition of lightning production during the mature phase of the storm when high radar reflectivities are detected by the radar. Not shown here, the MRR cells do not undergo this atypical behaviour, except one which can be considered as meaningless.

Finally, it is interesting to point out that cell 2 on 11 May and cell 3 on 7 July, which exhibit exceptionally high maximal flash rates (about 100 flashes/min), produce relatively few CG flashes. As a matter of fact, the mean CG percentages for both cells are $1.2 \%$ and $4.3 \%$, respectively.

\section{Discussion}

The use of a statistical test adapted to small samples points out marked differences between MRR and HRR cells. For most of the parameters considered in Table 1, the result of the Student test is close to 0, which means that identical behaviour between the two groups has low probability. Thus, the lightning activity of a storm can be different according to the value reached by the maximal radar reflectivity. However, the variances of each parameter are large. For example, the $+\mathrm{CG}$ percentage ranges from $0 \%$ to $100 \%$ for both groups, meanwhile the CG percentage ranges between about $1 \%$ to $35 \%$ for both groups too. As a matter of fact, it appears that none of the studied parameters can be used alone as an indicator to discriminate between MRR and HRR cells.

A remarkable observation of this study is that HRR storms produce on average more flashes (CG and IC) than MRR storms (Table 1). This result is consistent: cells 
exhibiting high reflectivities, and thus probably producing hail, are characterized by stronger updrafts, a larger spatial extension and a larger quantity of ice particles responsible for the charge separation mechanism. All these points contribute to the enhancement of lightning production. However, the observation cannot be applied to the cells individually considered since some MRR cells produced more flashes than some HRR cells.

As far as the + CG percentage is concerned, it seems to be lower for high-reflectivity cells than for MRR cells, which is contradictory with what is generally found in the literature (MacGorman and Burgess, 1994; Carey and Rutledge, 1998). According to Rakov (2003), high proportions of positive CG flashes originate from several conditions: in the dissipating stage of thunderstorms, when the upper positive region moves closer to the ground; in the stratiform region of MCS; in vertically little developed storms like winter storms; and in some severe storms for which the cause of the $+\mathrm{CG}$ production is unclear. One could wonder if the cells from the MRR group are less vertically extended. This could facilitate the production of $+\mathrm{CG}$ flashes from the upper positive region in the mature stage and/or when the cell is collapsing. Unfortunately, no continuous information about the vertical development is available to conclude on this hypothesis. However, the percentage of $+\mathrm{CG}$ flashes is greatly inhomogeneous in each group of cells, which is inconsistent with the existence of a unique behaviour.

In the same way, the comparison of the mean percentage of CG flashes (with respect to total flashes) for both groups shows a surprising result, with a higher value for HRR cells than for MRR cells. The detection of high reflectivity values corresponds to the presence of large amounts of precipitation and/or large precipitating particles. The growth of this precipitation requires the existence of strong updrafts and strong vertical development. Considering that high reflectivity values can be associated with strong updrafts, the present result is in disagreement with the elevated dipole hypothesis proposed by MacGorman et al. (1989). This theory supposes that the strong updrafts present in severe storms can lift the negative charge center to higher altitudes in the thundercloud and thus can favour IC flashes to the detriment of CG flashes. The HRR storms of the present paper most likely produced hail but they were probably not severe storms. Thus, the elevated charge theory, which is proposed in the literature to explain some observations in severe storms, is perhaps not approriate for most of the HRR cells considered in the study. However, two cells producing exceptionally high flash rates (11 May cell 2; 7 July cell 3) display very low CG flash numbers and therefore these two cases tend to support the elevated charge theory.

The lightning production and the radar reflectivity at low level display a simultaneous and similar evolution for most of the cells observed. Such behaviour is frequent in the case of classical convection, as observed by Soula and Chauzy (2001), who noted a very good correspondence between the time evolution of the total flash rate and that of the rainfall rate. Price and Federmesser (2006) also reported a strong correlation between the instantaneous rain rate and total flash rate in Mediterranean winter thunderstorms.

Besides, some cells show the occurrence of very high reflectivities (over $60 \mathrm{dBZ}$ ) at low level some tens of minutes after the peak of the total flash rate (6 May; 9 May; 2 July; 2 August; 19 August), suggesting that the growth phase of ice hydrometeors (about at least $10 \mathrm{~min}$ before precipitation is detected at low level) corresponds to an enhancement of electrification aloft. While iced hydrometeors are falling, the electrification is slowed down and the observation of high reflectivities at low level consequently coincides with a phase of lightning production decrease. This behaviour is that generally found in the literature for severe storms (Williams et al., 1999).

At last, several atypical cases are observed, characterized by a long period with high reflectivities and few flashes, followed by a second period with lower reflectivities and an increase of lightning activity. In these cases, the period characterized by high radar reflectivity values and weak lightning activity lasts between $45 \mathrm{~min}$ and $2 \mathrm{~h}$ before the occurrence of a strong increase of flash activity. This duration is long enough to suppose that the precipitation observed at low level resided at higher levels - where lightning flashes are usually initiated (see Proctor, 1991) - during the apparent lightning inhibition phase. Consequently, the low flash rates observed should be directly associated with high precipitation rates. Therefore, the interpretation of these atypical cases must take into account the presence of large precipitating particles aloft. Given the average duration of the $60 \mathrm{dBZ}$ detection for the 26 cells observed ( $42 \mathrm{~min}$ ) and an even longer duration of the $45 \mathrm{dBZ}$ detection, the presence of hail is likely in the precipitation, as observed by Fraile et al. (2001), who showed that the best variable for discriminating the occurrence of hail in thundercells with high reflectivity factors is the duration of the $45 \mathrm{dBZ}$ detection. Moreover, for several thundercells, their location and occurrence time allowed checking the hail presence from ground observations by meteorological services. Keeping in mind that very high radar reflectivities (higher than $60 \mathrm{dBZ}$ ) probably correspond to the 

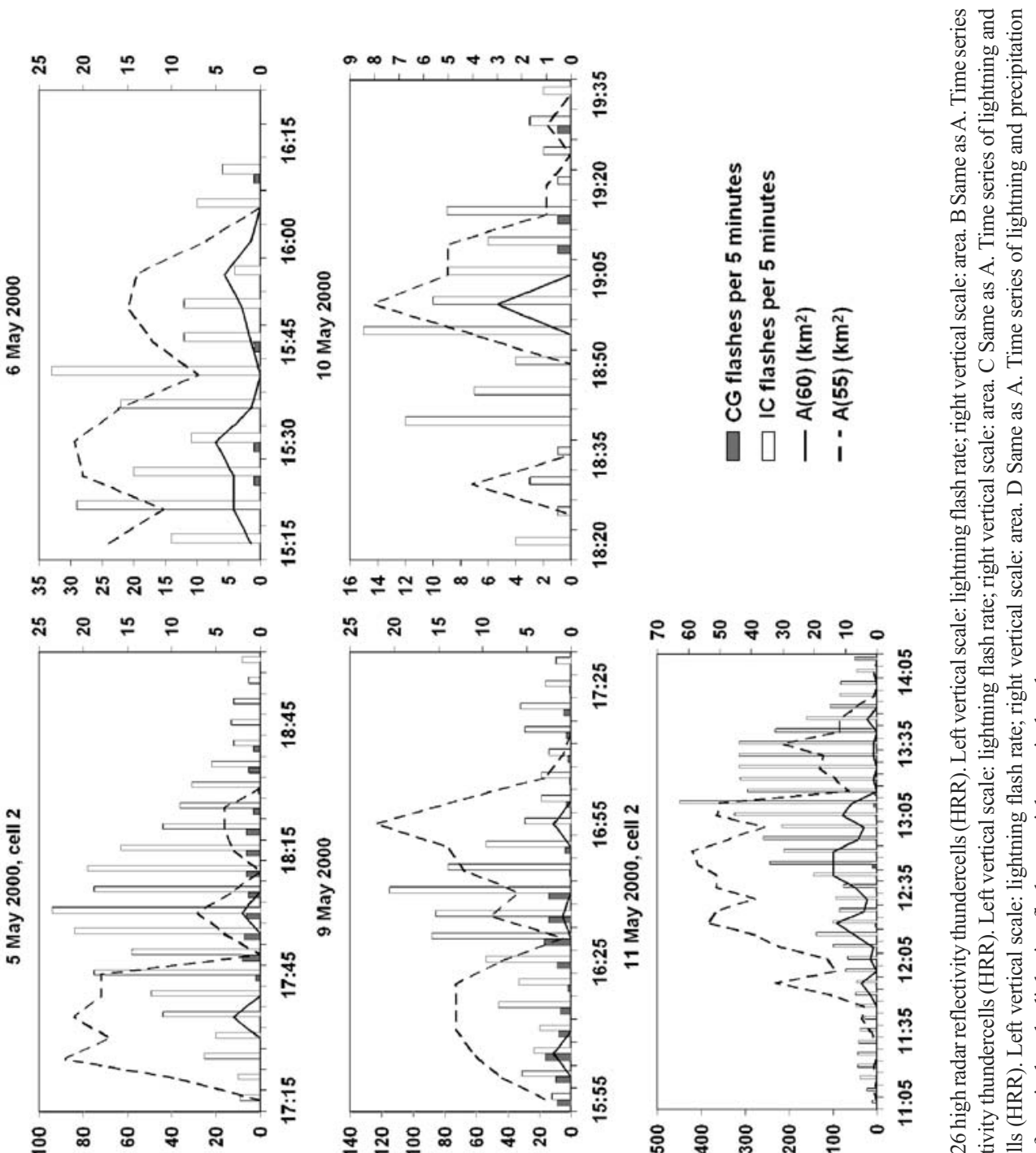

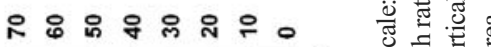

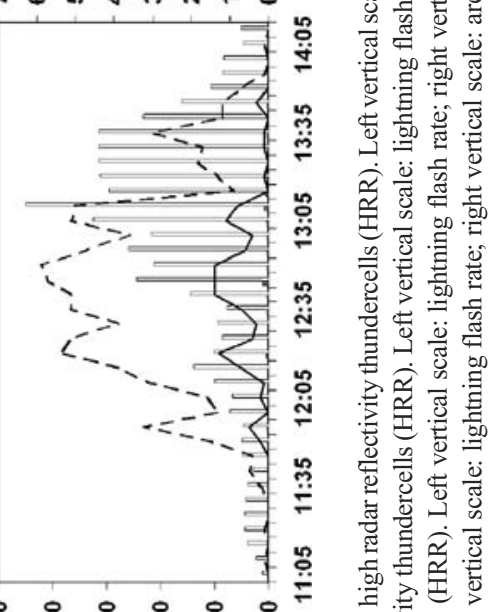

용요암 유 으.
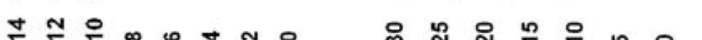

귱

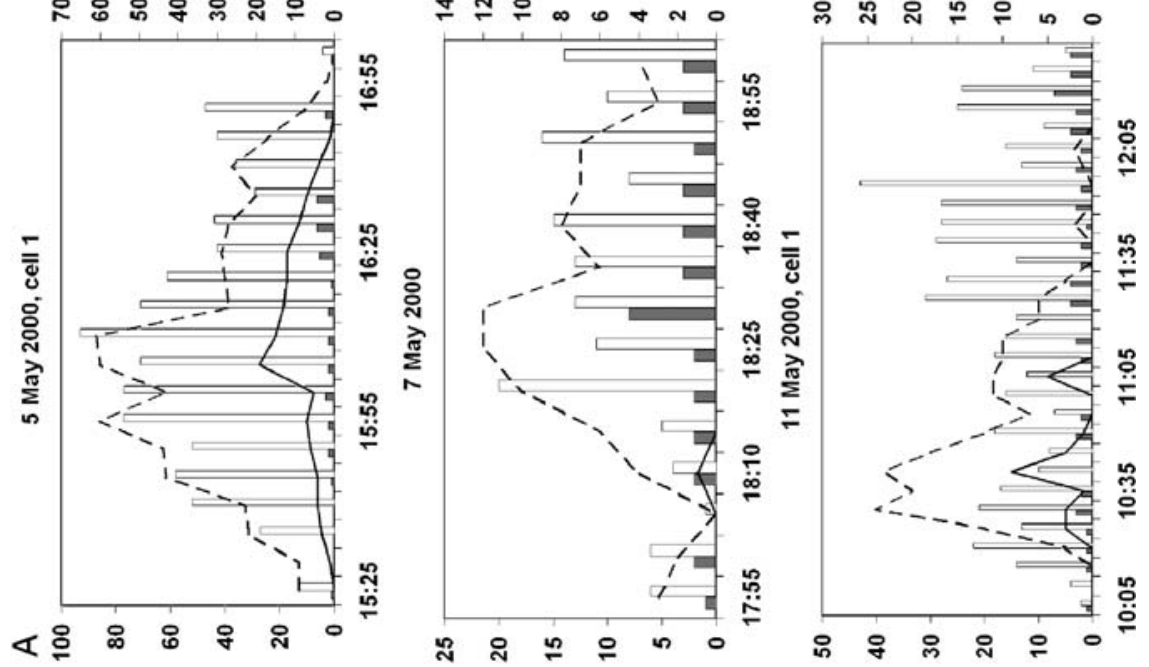

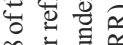

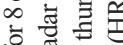

总

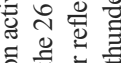

.

율

造

空 㐘

音

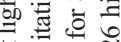

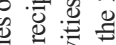

造总

ఏ

《是.

일 

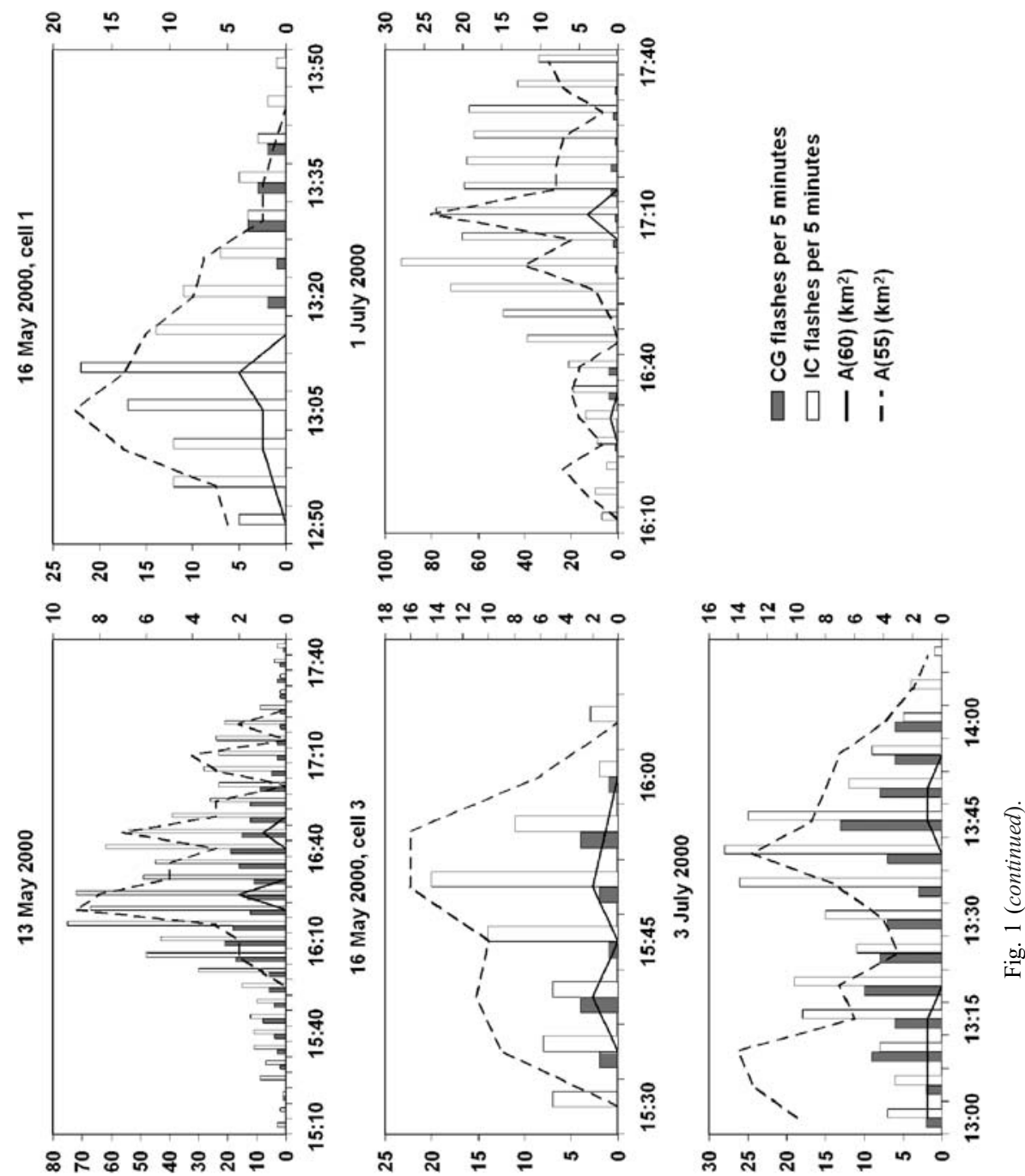

또으으뭉

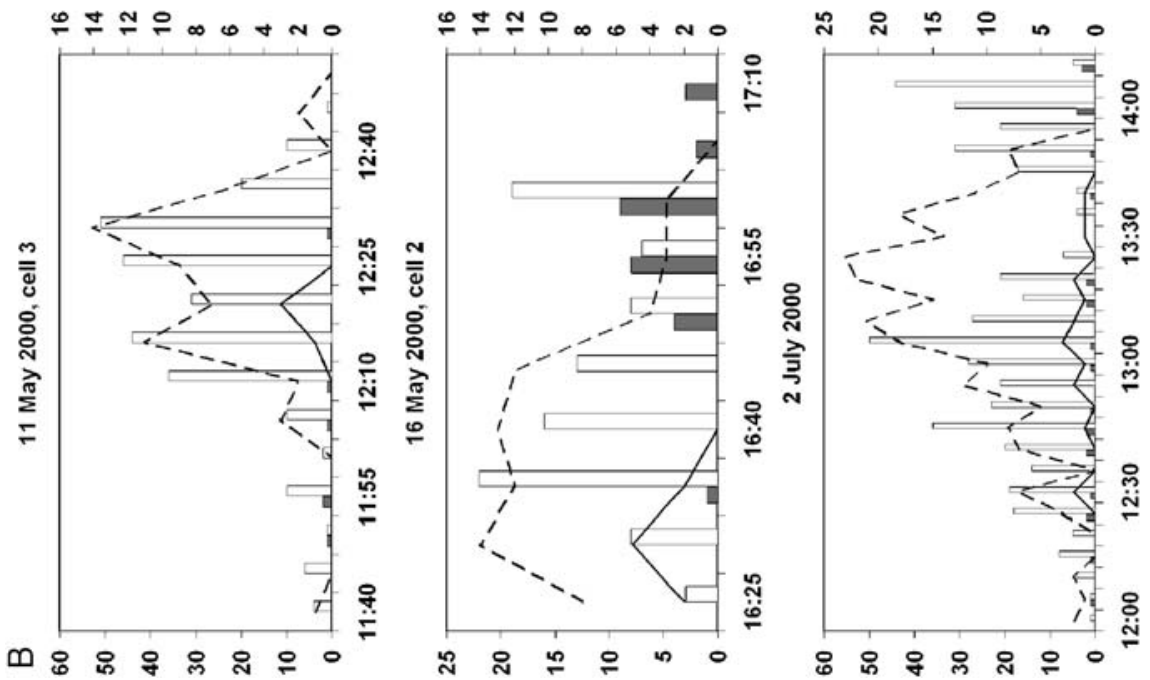



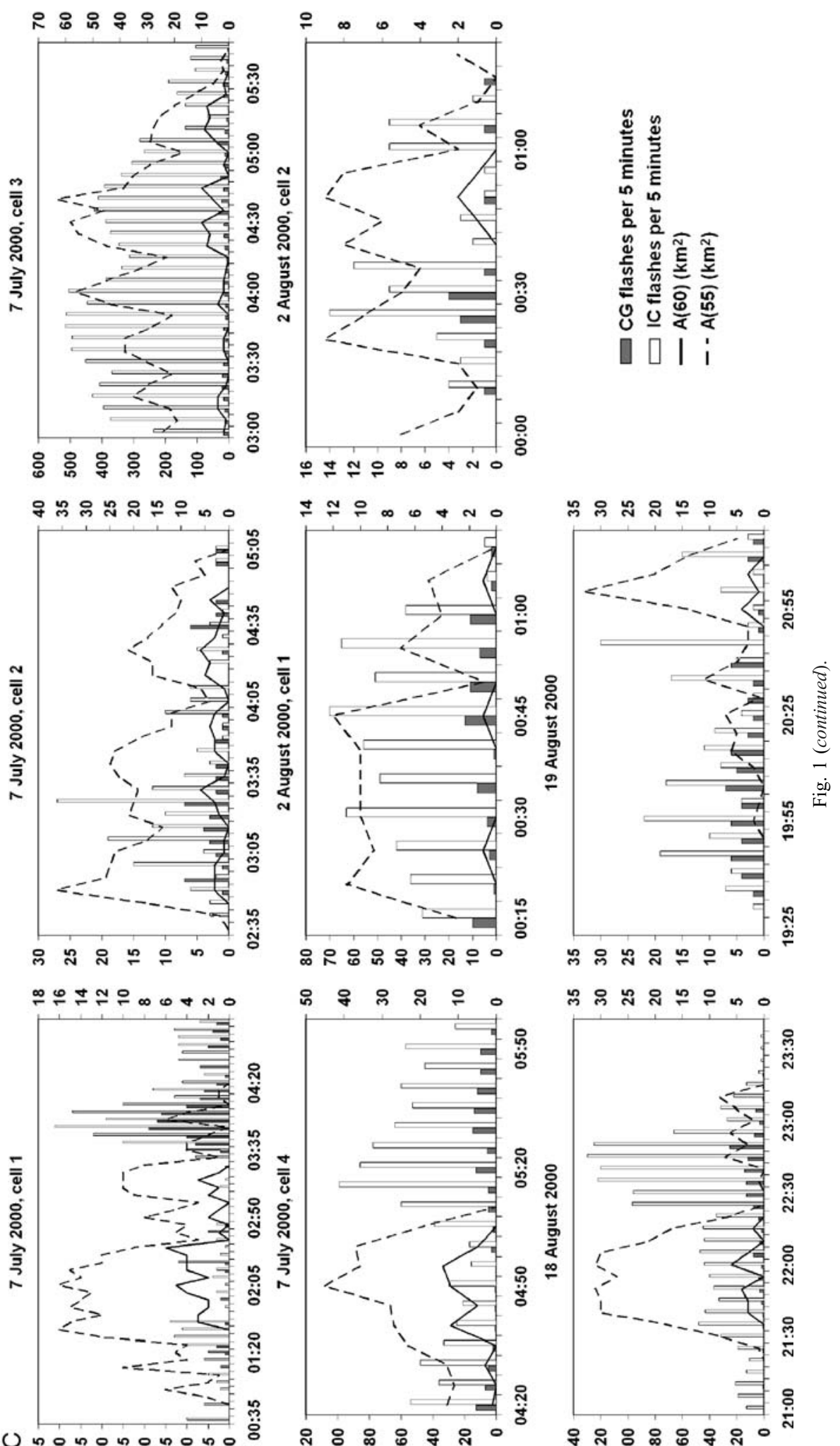

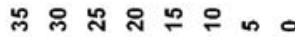

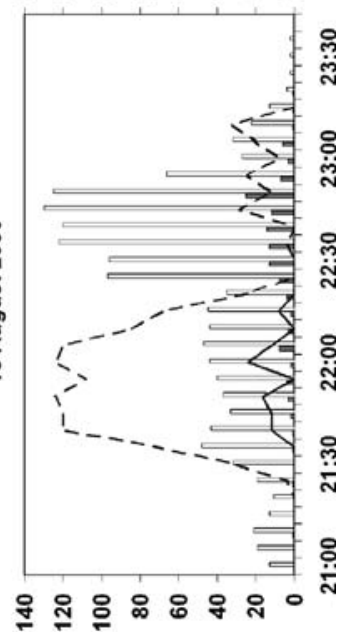



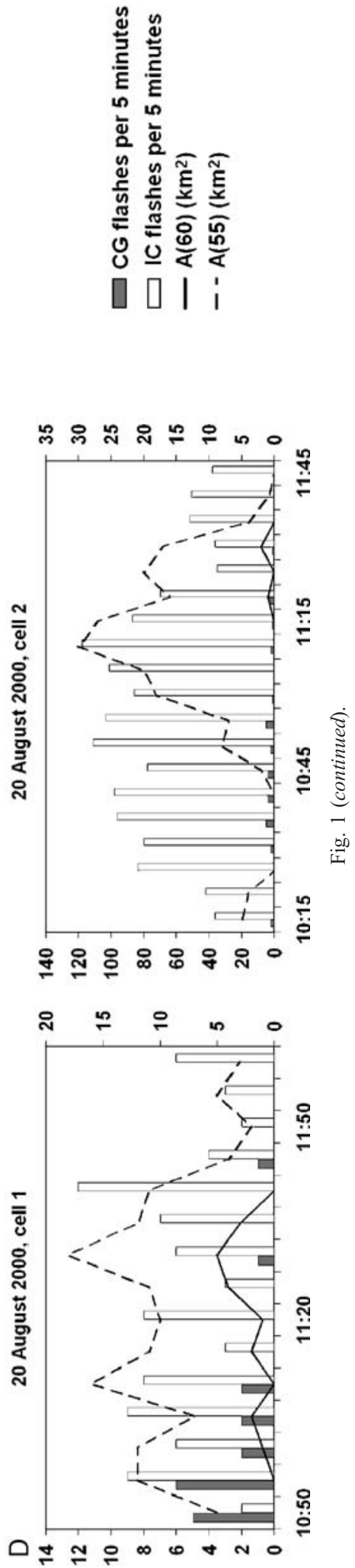

presence of hail, these cases raise the potential influence of hail on the various mechanisms that lead to lightning production.

Several possible explanations can be proposed to explain the low lightning activity associated with hydrometeor precipitation in these particular cells. They take into consideration three different causes: cloud dynamics, microphysics, and conditions for lightning initiation. Firstly, according to MacGorman et al. (1989), the strong updrafts responsible for the presence of hail do not allow hydrometeors to remain in a given layer of the thundercloud as long as in weaker updrafts. Therefore, the particles have less time to acquire charge and separate charge. There is less net charge in a given layer and thus, less lightning activity. This hypothesis could explain the low flash rates observed in these particular cells during the initial period with high reflectivities.

Secondly, one can assume that present observations result from the absence of microphysical conditions favorable for charge transfer mechanisms. The HRR cells produce a large amount of graupel, which tends to increase electrification. However, the ice particles responsible for radar reflectivities higher than $60 \mathrm{dBZ}$ are likely to have undergone wet growth (Atlas and Ludlam, 1961). According to Saunders and Brooks (1992), wet growth tends to inhibit the non inductive electrification process and thus, to limit lightning production. Yet, the low lightning activity period in the atypical events described in the present paper is rather long (from about $45 \mathrm{~min}$ to $2 \mathrm{~h}$ ) and one could wonder if wet growth conditions could exist during such a duration.

Finally, the low total flash rate could be issued from unfavorable conditions for lightning initiation. Electric breakdown in the first stage of the lightning process, and subsequently the discharge propagation at larger scale, have to be considered. At the present time, two distinct hypotheses may be considered as far as the first stage of the lightning discharge is considered: the runaway electron theory (Gurevich et al., 1992; Gurevich et al., 1999; Solomon et al., 2002), and the microphysical hypothesis in which the hydrometeor surfaces may act as corona emission sites (Crabb and Latham, 1974; Griffiths and Latham, 1974; Blyth et al., 1998; Schroeder et al., 1999; Coquillat et al., 2003). In the following, we focus on the microphysical hypothesis since hail is considered. At the micro scale, the occurrence of hail to the detriment of large distortable raindrops involved in glancing collisions - which are known to be one of the most efficient processes for corona emission (Blyth et al., 1998; Schroeder et al., 1999) could prevent the initiation of local breakdowns. This assumption seems to support the hypothesis that hail is present in these cells. On the other 
hand, hailstones are large particles that can enhance the local electric field, which is better for corona emission. If they undergo wet growth leading to the presence of a quasi-liquid layer at their surface, their electric conductivity is close to that of water, which allows comparable electric currents during microdischarges (Coquillat et al., 1995). But they remain non-deformable particles and are consequently less efficient in the first step of the initiation of a microdischarge. On a larger scale, the subsequent step concerns the propagation of discharges. Little is known at the present time on the interaction between a propagative discharge and the microphysical population in a thundercloud. Water drops are suspected to reinforce streamer propagation (Tardiveau and Marode, 2003) but the interaction of particles like hail has never been considered. Nevertheless, the knowledge about cloud discharge initiation and propagation is still too uncertain at present to formulate any definitive statement. Moreover, if hail is really present, the dimensions of the region containing hailstones are probably modest compared to that of a thundercloud, therefore one could wonder if the existence of this small region could affect the initiation in the entire cloud via the inhibition of the discharge propagation. Lang et al. (2005) reported that many VHF sources associated with CG flashes were located in small hail and high-density graupel volumes but not in large hail volumes (29 June 2000 and 5 July 2000). Wiens et al. (2005) observed surges of total and $+\mathrm{CG}$ flash rates during the intensification of severe storm updrafts and hail production aloft. However, the $+\mathrm{CG}$ flash rate reached its maximum and the total flash rate remained high when the hail echo and the updraft had been declining steadily. They observed that the total flash rate was less correlated with hail echo volume than with the volume of the updraft or the graupel echo. The lightning might avoid the hail shaft $(Z>55 \mathrm{dBZ})$, which suggests that hail plays a minor part in the electrification process, as expected, since its small surface integrated area does not favour collisional charging (Williams, 2001). The relatively small charges borne by hailstones prevent an intensification of the local electric field at their surface, which is necessary for corona emission.

These atypical cases raise questions that deal with many processes at various scales. None of the proposed hypotheses can provide a consistent explanation for the different behaviour between classical and atypical HRR cells. However, it is thought that the ice particle growth conditions are likely to differ from one cell to another, and therefore to affect the overall electrical behaviour of HRR cells. As a matter of fact, the growth conditions depend mainly on the rate of accretion of supercooled cloud droplets on graupel and hail (MacGorman and Rust, 1998). If this rate is high, the latent heat released by the freezing droplets warms the graupel, the surface of which remains liquid (wet growth) until it freezes. For example, this process is present in the strong updraft of thunderstorms because cloud droplets have less time to grow by collision and coalescence and are shifted aloft in the mixed phase region where they actively participate in the rime accretion process (for the supercell case, see MacGorman et al., 2005). On the contrary, if this rate is low, the surface of the graupel (or hail) remains frosted (dry growth). Actually, the rate of accretion depends on several parameters like, for instance, the updraft velocity, the liquid water content, the available water vapour, the number of cloud condensation nuclei, etc..., parameters that are likely to differ from one cell to another. It is therefore rather unlikely that two different cells undergo exact similar growth conditions, which renders difficult the analysis of the hail influence unless we could have benefit of upgraded radar observations. No doubt an exhaustive study of such events by means of volumetric and polarimetric radar observations could provide dynamical and microphysical features that could be helpful to understanding their complex behaviour. This is what we plan to do in the future with new data from the French radar network that is currently being upgraded.

\section{Conclusion}

A statistical study has been realized from $26 \mathrm{HRR}$ storms (exhibiting a maximal radar reflectivity higher than $60 \mathrm{dBZ}$ ) and $19 \mathrm{MRR}$ storms (exhibiting a maximal radar reflectivity between 50 and $55 \mathrm{dBZ}$ ) observed in the Paris area during summer 2000. The precipitation activity is estimated by using data from the Trappes Cband radar and the total lightning activity is issued from the French Météorage network and from a Safir device. The characteristics of the lightning activity for both groups of storms are compared. The evolution of the size of the area of high radar reflectivity at low level in the thundercloud and that of the flash rates are systematically analyzed for each HRR storm.

HRR cells present a longer lifetime, a more extended convective area and produce more CG and IC flashes than MRR cells. However, a large variability in the number, the rate and the type of flashes is observed in each group. The fact that the results are variable, especially the percentages of $+\mathrm{CG}$ and $\mathrm{CG}$, is interesting. That suggests there are cloud characteristics influencing charge separation and/or lightning initiation that are not fully identified.

The study of lightning production and radar reflectivity time series for each of the 26 HRR cells confirms a 
classical scheme characterized by a simultaneous evolution of lightning and precipitation activities. Some atypical cases though are observed. For these cells, lightning activity is first weak when strong precipitation is present at low level, and intensifies later, when reflectivities are lower. Possible explanations are propounded, such as: the high updraft speeds could reduce the particle charging duration, or the probable wetgrowth of hydrometeors could suppress charge separation, or the likely presence of hail could constitute an unfavorable condition for lightning initiation. Among the proposed hypotheses, none is fully satisfactory to account for the difference in behaviour between classical and atypical HRR cells. On the other hand, the ice particle growth conditions are probably a key process that drives the electrical behaviour of HRR cells. In order to better understand these unusual cases, it would be helpful to make use of advanced radar observations (i.e. polarimetric and multi-wavelength) so as to produce more accurate maps of hydrometeor locations and to distinguish wet particles from dry particles.

The present paper outlines some classical results about lightning activity in intense thunderstorms but also raises some questions by the observation of a quite large variability of behaviors. More accurate and complete observations would be needed in order to draw further conclusions.

\section{Acknowledgments}

The authors are grateful to Météo France, the French national weather organization, for providing the data for the radar observations and for the lightning activity detection with the Safir device in the region Ile de France. They thank the Météorage Company for providing $C G$ data from the French network.

\section{References}

Atlas, D.W., Ludlam, F.H., 1961. Multi-wavelength radar reflectivity of hailstorms. Q. J. R. Meteorol. Soc. 87, 523-534.

Auer Jr., A.H., 1994. Hail recognition through the combined use of radar reflectivity and cloud-top temperatures. Mon. Weather Rev. 122, 2218-2221.

Austin, P.M., 1987. Relation between measured radar reflectivity and surface rainfall. Mon. Weather Rev. 115, 1053-1070.

Battan, L.J., 1973. Radar Observations of the Atmosphere. The University of Chicago Press, Chicago, Illinois. 324 pp.

Blyth, A.M., Christian, H.J., Latham, J., 1998. Corona emission thresholds for three types of hydrometeor interaction in thunderclouds. J. Geophys. Res. 103, 13975-13977.

Branick, M.L., Doswell III, C.A., 1992. An observation of the relationship between supercell structure and lightning ground strike polarity. Weather Forecast. 7, 143-149.
Carey, L.D., Rutledge, S.A., 1998. Electrical and multiparameter radar observations of a severe hailstorm. J. Geophys. Res. 103 (D12), 13,979-14,000.

Carey, L.D., Rutledge, S.A., Petersen, W.A., 2003. The relationship between severe storm reports and cloud-to-ground lightning polarity in the contiguous United States from 1989 to 1998. Mon. Weather Rev. 131, 1211-1228.

Changnon, S.A., 1992. Temporal and spatial relations between hail and lightning. J. Appl. Meteorol. 31, 587-604.

Coquillat, S., Chauzy, S., Médale, J.C., 1995. Microdischarges between ice particles. J. Geophys. Res. 100, 14327-14334.

Coquillat, S., Combal, B., Chauzy, S., 2003. Corona emission from raindrops in strong electric fields as a possible discharge initiation: comparison between horizontal and vertical field configurations. J. Geophys. Res. 108 (D7), 4205, doi:10.1029/ 2002JD002714.

Crabb, J.A., Latham, J., 1974. Corona from colliding drops as a possible mechanism for the triggering of lightning. Q. J. R. Meteorol. Soc. 100, 191-202.

Cummins, K.L., Murphy, M.J., Bardo, E.A., Hiscox, W.L., Pyle, R.B., Pifer, A.E., NLDN'95, 1998. A combined TOA/MDF technology upgrade of the US National Lightning Detection Network. J. Geophys. Res. 103, 9,035-9,044.

Fraile, R., Castro, A., Sánchez, J.L., Marcos, J.L., López, L., 2001. Noteworthy C-band radar parameters of storms on hail days in northwestern Spain. Atmos. Res. 59-60, 41-61.

Fulton, R.A., Breidenbach, J.P., Seo, D.J., Miller, D.A., O’Bannon, T., 1998. The WSR-88D rainfall algorithm. Weather Forecast. 13, 377-395.

Griffiths, R.F., Latham, J., 1974. Electrical corona from ice hydrometeors. Q. J. R. Meteorol. Soc. 100, 163-180.

Gurevich, A.V., Milikh, G.M., Roussel-Dupre, R., 1992. Runaway electron mechanism of air breakdown and preconditioning during a thunderstorm. Phys. Lett., A 165, 463-468.

Gurevich, A.V., Zybin, K.P., Roussel-Dupre, R., 1999. Lightning initiation by simultaneous effect of runaway breakdown and cosmic ray shower. Phys. Lett., A 254, 79-87.

Knupp, K.R., Paech, S., Goodman, S., 2003. Variations in cloud-toground lightning characteristics among three adjacent tornadic supercell storms over the Tennessee valley region. Mon. Weather Rev. 131, 172-188.

Lang, T.J., Rutledge, S.A., 2002. Relationships between convective storm kinematics, precipitation, and lightning. Mon. Weather Rev. 130, 2492-2506.

Lang, T.J., Rutledge, S.A., Dye, J.E., Venticinque, M., Laroche, P., Defer, E., 2000. Anomalously low negative cloud-to-ground lightning flash rates in intense convective storms observed during STERAO-A. Mon. Weather Rev. 128, 160-173.

Lang, T.J., Miller, L.J., Weisman, M., Rutledge, S.A., Barker III, L.J., Bringi, V.N., Chandrasekar, V., Detwiler, A., Doesken, N., Helsdon, J., Knight, C., Krehbiel, P., Lyons, W.A., MacGorman, D., Rasmussen, E., Rison, W., Rust, W.D., Thomas, R.J., 2005. The severe thunderstorm electrification and precipitation study. Bull. Am. Meteorol. Soc. 1107-1125 (August).

MacGorman, D.R., Burgess, D.W., 1994. Positive cloud-to-ground lightning in tornadic storms and hailstorms. Mon. Weather Rev. 122 (8), 1671-1697.

MacGorman, D.R., Rust, W.D., 1998. The Electrical Nature of Storms. Oxford University Press, New York, USA. 422 pp.

MacGorman, D.R., Burgess, D.W., Mazur, V., Rust, W.D., Taylor, W.L., Johnson, B.C., 1989. Lightning rates relative to tornadic storm evolution on 22 May 1981. J. Atmos. Sci. 46, 221-250. 
MacGorman, D., Rust, W.D., Krehbiel, P., Rison, W., Bruning, E., Wiens, K., 2005. The electrical structure of two supercell storms during STEPS. Mon. Weather Rev. 2583-2607 (September).

Mason, B.J., 1971. The Physics of Clouds. Clarendon Press, Oxford, UK.

Orville, R.E., Huffines, G.R., 2001. Cloud-to-ground lightning in the United States: NLDN results in the first decade, 1989-98. Mon. Weather Rev. 129, 1179-1193.

Price, C., Federmesser, B., 2006. Lightning-rainfall relationships in Mediterranean winter thunderstorms. Geophys. Res. Lett. 33, L07813, doi:10.1029/2005GL024794.

Proctor, D.E., 1991. Regions where lightning flashes began. J. Geophys. Res. 96, 5099-5112.

Rakov, V.A., 2003. A review of positive and bipolar lightning discharges. Bull. Am. Meteorol. Soc. 767-775.

Reap, R.M., MacGorman, D.R., 1989. Cloud-to-ground lightning: climatological characteristics and relationships to model fields, radar observations, and severe local storms. Mon. Weather Rev. $117,518-535$.

Richard, P., Lojou, J.Y., 1996. Assessment of application of storm cell electrical activity monitoring to intense precipitation forecast. Proceedings of the 10th International Conference on Atmospheric Electricity, June 10-14, Osaka, Japan, pp. 284-287.

Salek, M., Cheze, J.L., Handwerker, J., Delobbe, L., Uijlenhoet, R. 2004. Radar techniques for identifying precipitation type and estimating quantity of precipitation, European Cooperation in the Field of Scientific and Technical Research, Document of COST Action 717, WG 1, Task WG 1-2.

Saunders, C.P.R., Brooks, I.M., 1992. The effects of high liquid water content on thunderstorm charging. J. Geophys. Res. 97, 14671-14676.

Schroeder, V., Baker, M.B., Latham, J., 1999. A model study of corona emission from hydrometeors. Q. J. R. Meteorol. Soc. 125, 1681-1693.

Seimon, A., 1993. Anomalous cloud-to-ground lightning in a F5tornado-producing supercell thunderstorm on 28 August 1990. Bull. Am. Meteorol. Soc. 74, 189-203.
Solomon, R., Adamo, C., Baker, M., 2002. A lightning initiation mechanism: application to a thunderstorm electrification model. C. R. Physique 3, 1325-1333.

Soula, S., Chauzy, S., 2001. Some aspects of the correlation between lightning and rain activities in thunderstorms. Atmos. Res. 56, 355-373.

Soula, S., Seity, Y., Feral, L., Sauvageot, H., 2004. Cloud-to-ground lightning activity in hail-bearing storms. J. Geophys. Res. 109 (D2), D02101, doi:10.1029/2003JD003669.

Stolzenburg, M., 1994. Observations of high ground flash densities of positive lightning in summertime thunderstorms. Mon. Weather Rev. 122, $1740-1750$.

Stolzenburg, M., Rust, W.D., Smull, B.F., Marshall, T.C., 1998. Electrical structure in thunderstorm convective regions, 1. Mesoscale convective systems. J. Geophys. Res. 103 (D12), 14059-14078.

Tardiveau, P., Marode, E., 2003. Point-to-plane discharge dynamics in the presence of dielectric droplets. J. Phys. D: Appl. Phys. 36, 1204-1211.

Wacker, R.S., Orville, R.E., 1999a. Changes in measured lightning flash count and return stroke peak current after the 1994 U.S. National lightning detection network upgrade: 1. Observations. J. Geophys. Res. 104, 2151-2158.

Wacker, R.S., Orville, R.E., 1999b. Changes in measured lightning flash count and return stroke peak current after the 1994 U.S. National lightning detection network upgrade: 2. Theory. J. Geophys. Res. 104, 2159-2162.

Wiens, K.C., Rutledge, S.A., Tessendorf, S.A., 2005. The 29 June 2000 supercell observed during STEPS. Part II: lightning and charge structure. Mon. Weather Rev. 4151-4177 (December).

Williams, E.R., 2001. The electrification of severe storms, severe convective storms. Meteorol. Monogr. 28 (50), 527-561.

Williams, E., Boldi, B., Matlin, A., Weber, M., et al., 1999. The behavior of total lightning activity in severe Florida thunderstorms. Atmos. Res. 51, 245-265. 